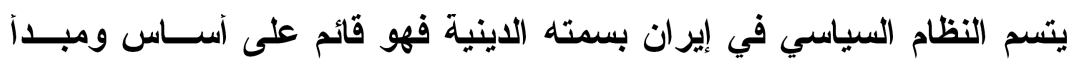

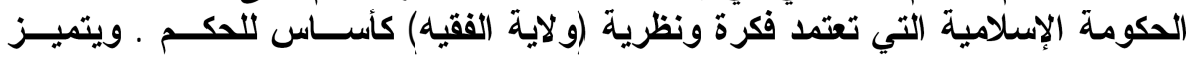

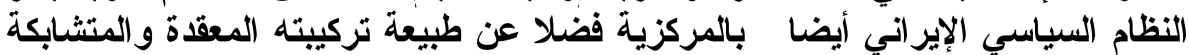

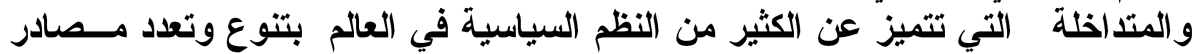

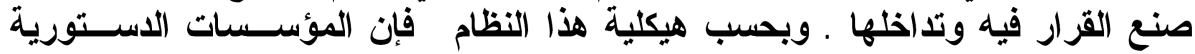

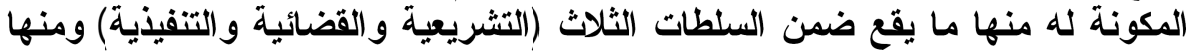

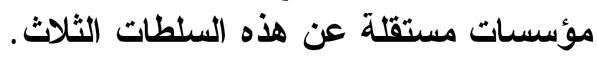

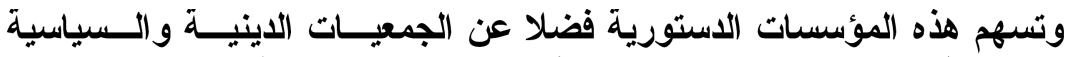

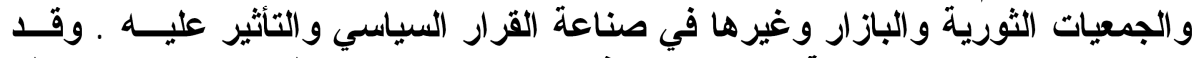

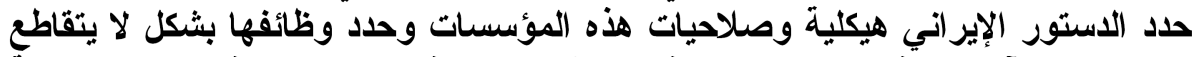

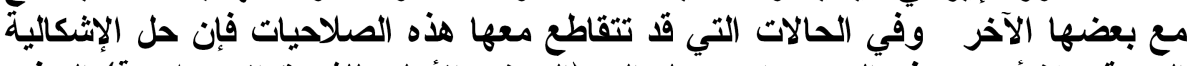

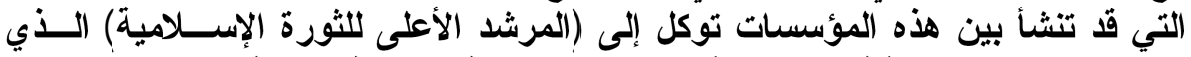

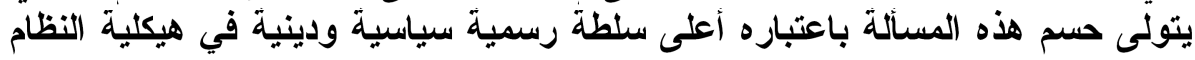
السياسي الإير اني.

ملخل

تعد إيران إحدى دول الجوار للوطن العربي من جهته الشرويه، وهي بموفعهـ

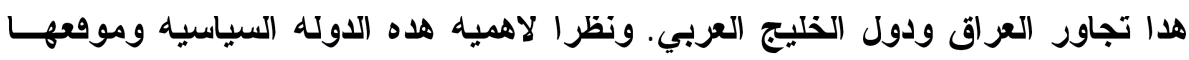
الاستراتيجي المطل على الخليج العربي هضلا عن علاهاتها التاريخيه مع البلدان العربيه الاخرى بشكل عام و دول الخليج العربي بشكل خاص، وقل ارتاى الباحث في بحته هلاه

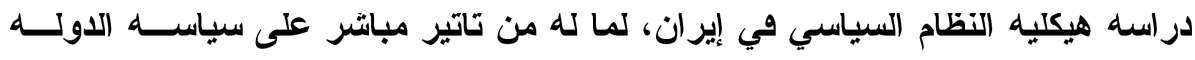

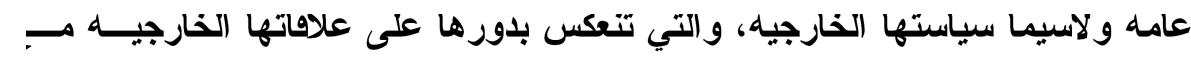
* مدرس، صسم الاراسات التاريخيه و التوتيق، مركز الدراسات الإلكيميه - جامعه الموصل -العراق. 
دول العالم وبخاصه البلان المجاورة ومنها العربيه. هضلا عن بيان هيكليه هدا النظــام للباحتين و المؤرخين و المهتمين بها المجال.

ومن المفيل الاثشارة الى ان هدا النظام يتميز بتعدد مصادر صنع القرار ويه وتتوع

مؤسساته الاستوريه، ويكاد ينقرد بطبيعته هلده عن الكتير من النظم السياسيه القائمسـه في دول العالم. وبحسب هله الميزات هان المؤسـسـات الاســتوريه المكونــهـ للنظــام السياسي في إيران، منها ما يقع ضمن السلطات التلات (التشريعيه، القضائيه، التتفيديه) ومنها مؤسسات مستقكه عن هده السلطات التلات. وضد رسم الاستور الإيراني هيكلي ة

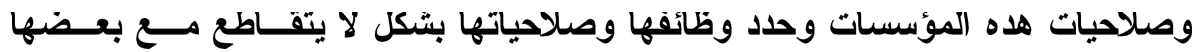

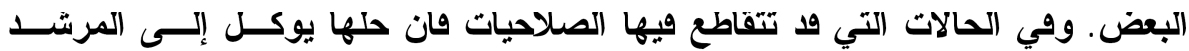
الاعلى للتورة الإسلاميه (القائد) الدي يعد اعلى سلطه وي فمه الهرم السياسي الإيراني.

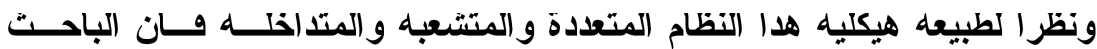
ارتاى تقسيم البحث ودراسته بحسب الاهيه السياسيه والسلطه الإداريه التي تتمتع بها

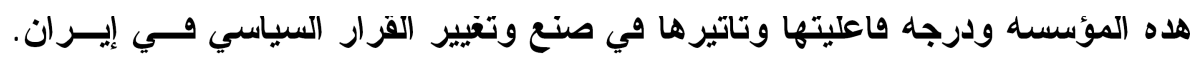
وعليه ياتي في مقدمه هده المؤسسات او السلطات:

اولا: المرشد الاعلى للتورة الإسداميه|(القائد) يتصف النظام السياسي الإيراني بسمته الدينيه، وهو فائم على مبداين اساســين

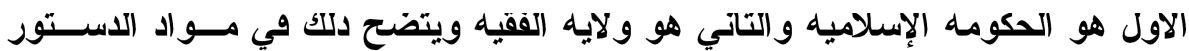

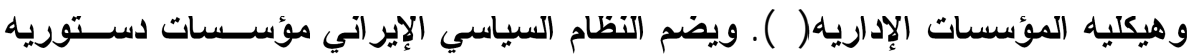
واخرى غير دستوريه تؤتر ايضا في عمليه صنع القرار السياسي|*). وصد اكلات بنود الاستور الإيراتي في معظمها على إسلاميه النظام، من خــلال

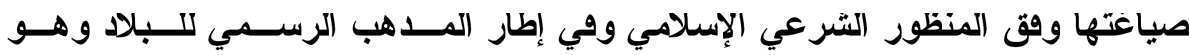
المدهب|(الإتي عشري)، واشارت المادة الرابعه من الدستور إلى ان الموازين الإسلاميه

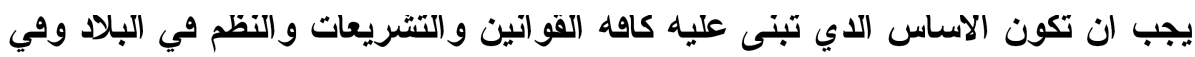

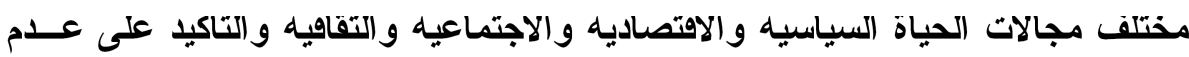
إصدار او تبني اي فانون او تشريع يخالف الشرع الإسلامي(بان).

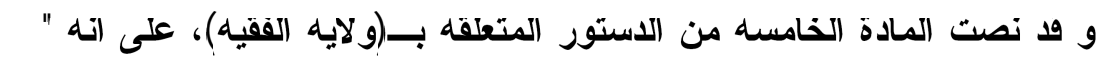
زمن غياب الإمام المهـي، تكون ولايه الامر و إمامه الامــه وـــي جمهوريــهـ إيــران 
الإسلاميه بيد الفقيه العادل"(r))، و الققيه العادل الدي يتولى زمام القيــادة و إدارة الــبلاد

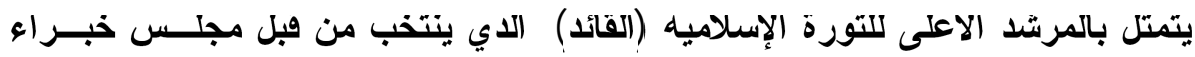
(القيادة) (ع).

يمتل منصب المرشد الاعلى للتورة الإسلاميه في النظام الــسياسي الإيرانــي

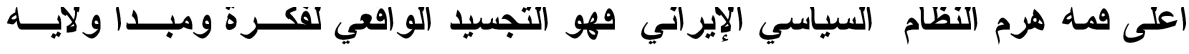
الفقيه، التي يقوم عليها هدا النظام. وصد منح الاستور الإيراني الصادر عسام $19 V 9$

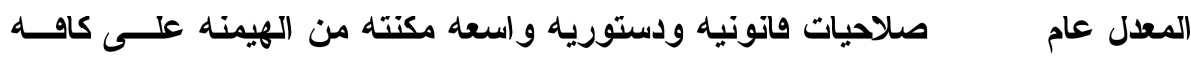
مؤسسات الدوله، وبالتالي وله الحق في التلخل في عمل هده المؤسسات بشكل مباشر،

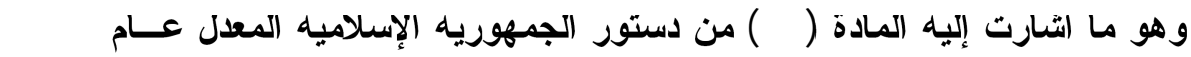
(0) وصد نصت هلده المادة على ان" السلطات الحاكمه في جمهوريه إيـران الإســلاميه هي: السلطه التشريعيه والسلطه التنقيايه والسلطه الفـضائيه، وتمــارس صــلاحياتها باشر اف ولي الامر المطلق وإمام الامه ودلك ووقا للمواد الكلاحقه وي هدا الدستور"(7). وبحسب دستور عام 19V9 والتعديل الاي شهده عام 1919 وـــان صــلاحيات ومسؤوليات المرشد الاعلى للتورة الإسلاميه (القائد) تتجسد بالاتي: I .تعيين السياسات العامه للاوله وبالتشاور مع مجمع تثخيص مصلحه النظام. م.الإشر اف على تتقيا سياسات الدولة. r. م.إصدار امر الاستقتاء العام. ع.تولي القيادة العامه للقوات المسلحه. 0.إعلان الحرب والسلام والنقير العام. 7.تعيين وعزل كل من: إبـققهاء مجلس صيانه الدستور . ب -اعلى مسؤول في السلطه القضائيه. ج -رئيس مؤسسه الإداعه و التتلزيون. لد -رئيس اركان القيادة المشتركه. هـ ـ-القائد العام لقوات حرس التورة الإسلاميه. 
و - القيادات العليا للقوات المسلحه وووى الامن الداخلي.

ومعالجه الخلاهات التي ود تتشا بين السلطات التلات (التشريعيه والقضائيه والتقبيديه)

هضلا عن تنظيم العلاهات بينهم.

A.معالجه المشاكل التي تواجه النظام السياسي والتي صد يتعدر حلها من خلائ مؤسسات

$$
\text { الدوله الاخرى. }
$$

9.إصرار تنصيب رئيس الجمهوريه، بعد ان تتم عمليه انتخابه.

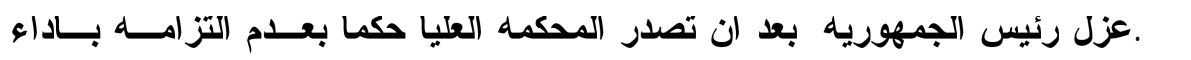

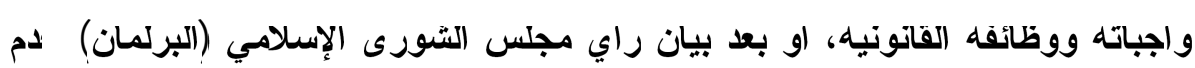

كفائته السياسيه.

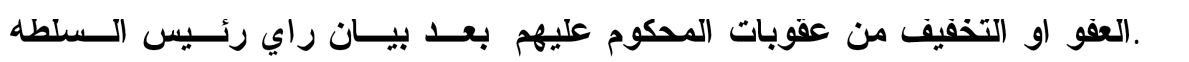

(القضائيه(V).

إن المتابع للتعديلات التي شهدها الاســتور الإيرانــي عــام 1919 والخاصــهـ

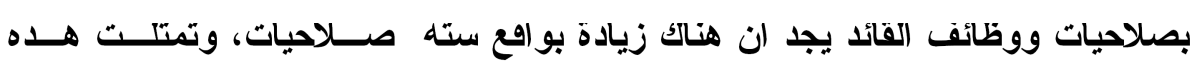

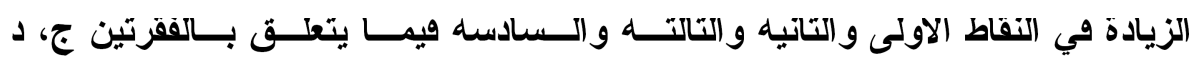

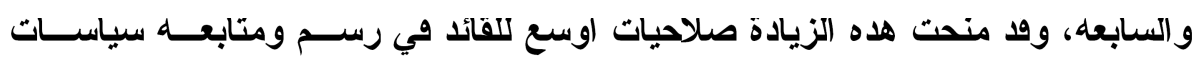

الدوله و التدخل في عمل كامه المؤسسات الإداريه/( ).

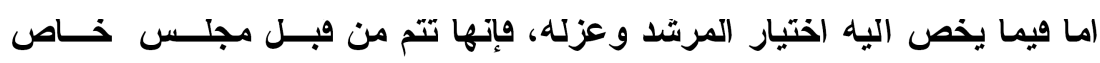

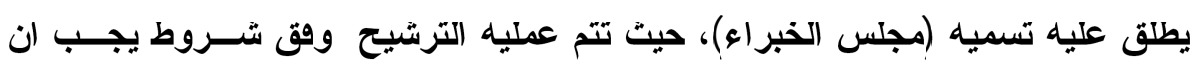
تتوفر وي شخص المرشتح وتتمتل في: تشئه

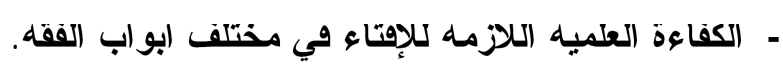

- العداله و التقوى اللازمتان لقيادة الامه الإسلاميه.

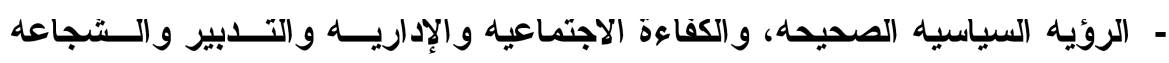

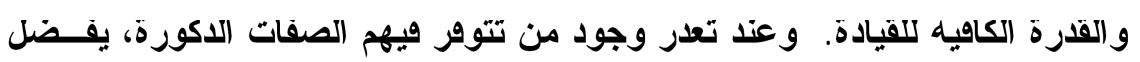

من كان له رؤيه وقهيه وسياسيه (ووى من غيره(9).

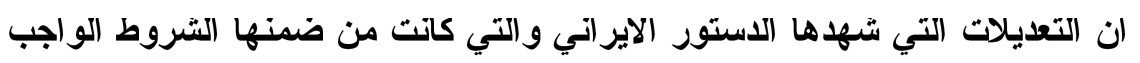

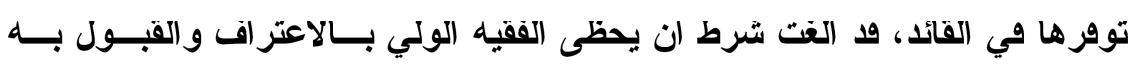

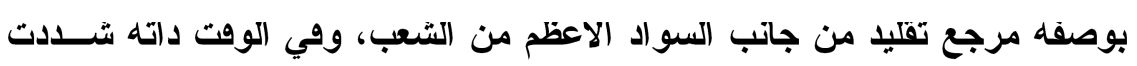

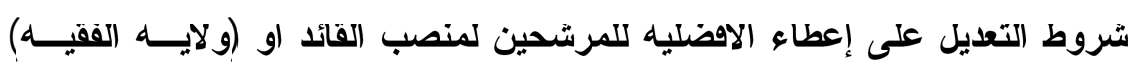


و الدين يجب ان يتبتون درايتهم الواسعه في القضايا السياسيه والاجتماعية، وبهـا تكون شروط التعديل وا خفقت من المعرهه الققهيه وشدادت على الخبرة الــسياسيه و الاجتماعيه| - (1).

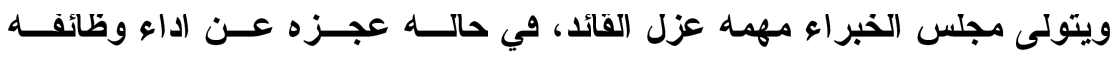
القاتونيه،او وقد احد الثروط الانقه الدكر، وفي حاله المرض او الوقاة او الاستقالة، يتولى مجلس شورى مؤلف من رئيس الجمهوريه ورئيس السلطه القضائيه واحد وقهاء

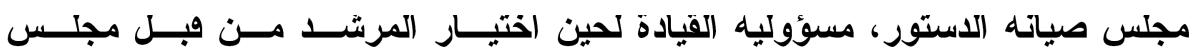
(أخبر (1) (1) ).

ولمؤسسه القيادة هيكليه إداريه وموظفين وفريق من المستثنارين، وــلا عـن

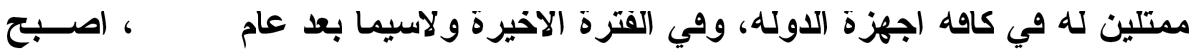
للمرشد جهاز مخابرات خاص به مستقل فـي عمــهـه عـن عـــل وزارة المخــابرات و الامن(1) (1). ويمارس القائد مهامه الوظيقيه من خلال مكتب خاص به يطلق عليه تسميه مكتب

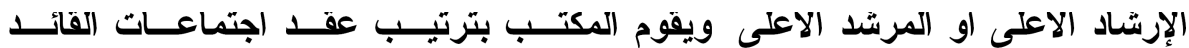
ومناسبات ظهوره وزيار اته، كما يقوم بإطلاعه على اخر الاحدات والتطورات السياسيه

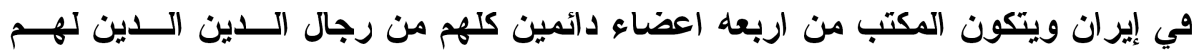
درجه (حجه الإسلام) او (ايه الله)، كما يعمل في هلا المكتب عشرة مستشارين للشؤون

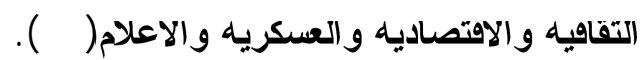

\section{ثانيا: السلطه التتقيديه}

تتمتل السلطه التتفيديه وي النظام السياسي الإيراني، برئيس الجمهوريه الـــي

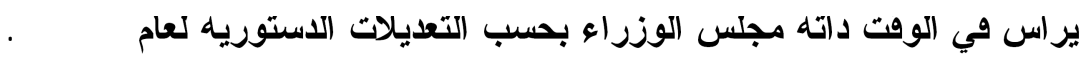
و يحتل رئيس الجمهوريه المرتبه التانيه بعد منصب المرشند او الفائد في النظــام

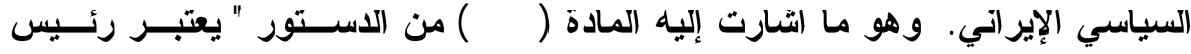

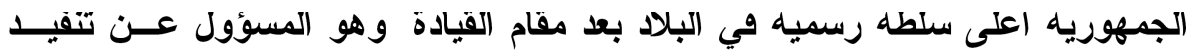




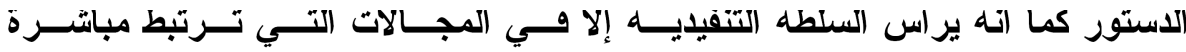
بالقيادة'(ع) وهقا لهله المادة مان رئيس الجمهوريه يتولى مسؤوليه السلطه التتقيديه

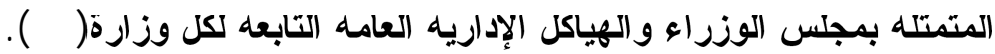
ويتتب منصب رئيس الجمهوريه من هبل الشبب بشكل مباشر. ومهـدة الــدورة الواحدة اربع سنوات هابله للتجديد مرة واحدة هقط (المادة ع ا I)، ويشترط فـي هـوزه

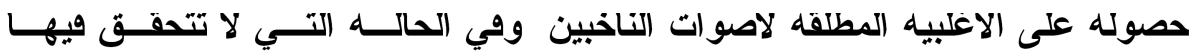
الغالبيه، وتتم إعادة الاتتخابات مرة تانيه، بعد مرور اسـبـوع واحـــ علــى الاتتخابــات الاولى. وتحصر الاتتخابات التانيه بمرشحين وقط من مجموع المرشحين وــي الــدورة

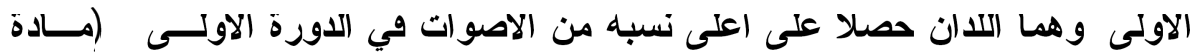
و و (I IV هيحل مكانه الثخص الدي كان له اكتر نسبه من الاصوات في الــدورة الاولــى إمسادة (17) (1 IV ويتولى مجلس صياته الاستور عمليه الإثراف على انتخابات رئاسده الجمهوريــهـ (مادة 11 1). وتتم عمليه انتخاب الرئيس الجديد لجمهوريه إيران الإسلاميه، وبل شهر واحد على اول تقاير من انتهاء دورة الرئيس السابق (مادة 19 ) مع استمرار الرئيس السابق في منصبه، خلال الفترة بين انتهاء الدورة وحتى انتخاب الرئيس الجديا(IV)( بعد ان تتم عمليه اتتخاب رئيس الجمهوريه، يقوم الاخير بتاديه اليمين الدستوريه

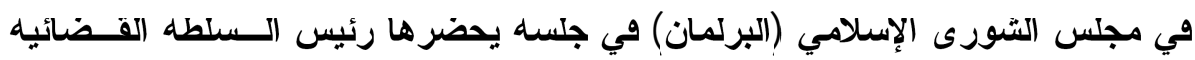

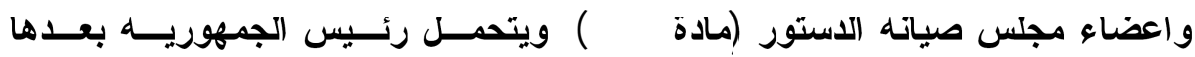
مسؤوليه الرئاسه، ويكون مسؤولا امام الثعب والقائد ومجلس الثورى الإسلاهي (مادة

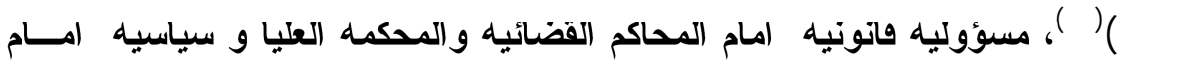

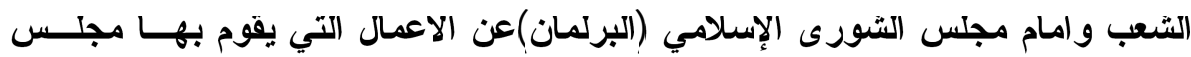

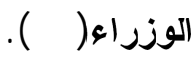

وحدد الاستور الإيراني الشروط الواجبه توفرها وي المرشحين لمنصب رئيس

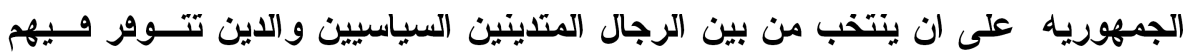

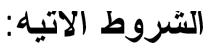
• ان يكون إيراني الاصل ويحمل الجنسيه الإيرانيه.

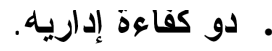




$$
\text { • . دو ماض جيد. }
$$

• مؤمنا ومعتقا بمبادئ جمهوريه إيران الإسلاميه و المدهب الرسمي للبلاد| - م).

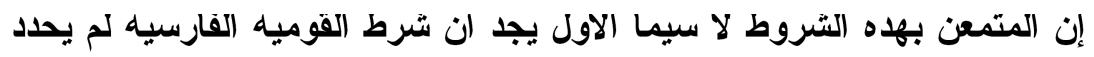
في المرشحين لاته حدل ان يكون المرشتح إيراني الاصل ويحمل الجنـسيه الإيرانيـهـه وول تحقق شرط القوميه الفارسيه في جميع الدين شفلوا منصب رئيس الجمهوريه ويـي

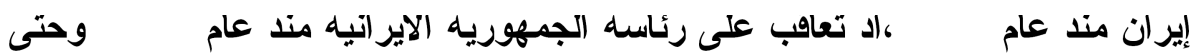

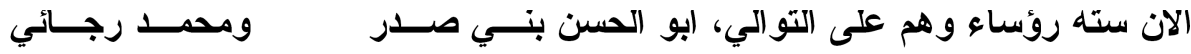

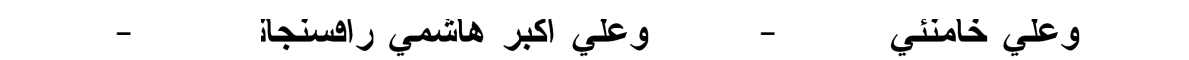

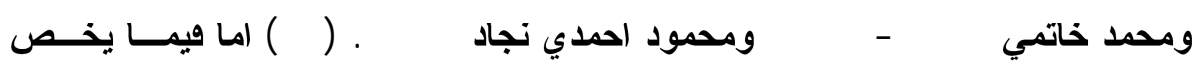
الثرط الخامس، واته حدد ان يكون رئيس الجمهوريه مسـسلما ومــن اتبــاع المـــهب الجعقري الاتتي عشري حصرا، بحسب (المادة II) التي نصت على ان الدين الرسئسي

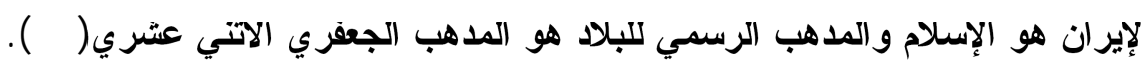

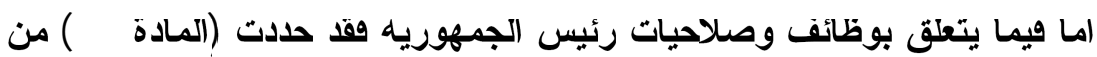
اللستور الخطوط الاسـاسيه لها، وهي ان يتولى رئيس الجمهوريــهـه والــوزراء مهرهـهـ ممارسه السلطه التتقيديه شريطه ان لا تتقاطع مع صلاحيات القائد التي اقرها الاستور

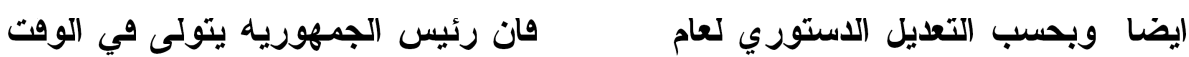
داته رئاسه مجلس الوزراء. ويشرف من خلاله على عمل الــوزراء والتــسيق بــين

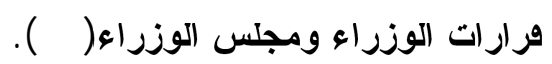

$$
\text { وتتلخص المهام الاساسيه لرئيس الجمهوريه بالاتي: }
$$

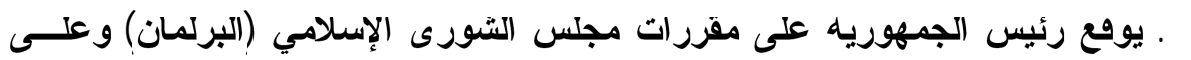
تتيجه الاستفتاء العام. بعد مرورها بالمراحل القانونيه و إبلاغها إياه، وعليه ان يسلمها لإنيا

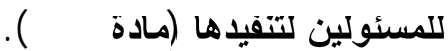

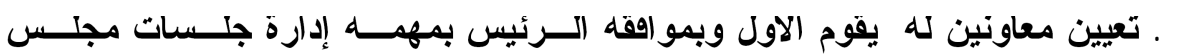
الوزراء والتنسيق بين سائر الوزارات (مادة عrrا). 
r. يوفع رئيس الجمهوريه او ممتله القاتوني وبعد مصادوه مجلس الشورى الإســلامي على المعاهدات والاتفافيات والمواتيق التي تبرم بين الحكومه الإيرانيه وسائر الــــول وكللك المعاهدات المتعلقه بالاتحادات الدوليه (مادة وم 1) . ع. تولي مسؤوليه التخطيط والميزاتيه والاعمال الإداريه و الوظيفيه للبلاد بشكل مباشر او يوكل شخصا اخر لادارتها (مادة 7r1). 0. يحق لرئيس الجمهوريه وبعد مصادوه مجلس الوزراء ووي حالات خاصسـه، تعيسين متل خاص له او عدة ممتلين ميع تحديل صلاحياتهم، وفي هلده الحاله، تكــون فــرارات الممتلين بمتابه ورارات رئيس الجمهوريه ومجلس الوزراء (مادة ITVV). 7. تعيين السفراء باقتراح من هيل وزير الخارجيه ومصادهه رئيس الجمهوريهه الـــي

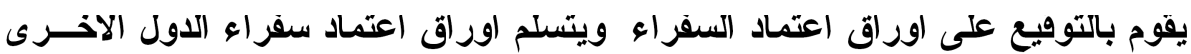

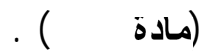

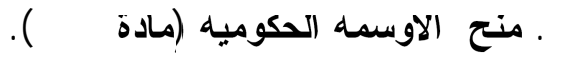

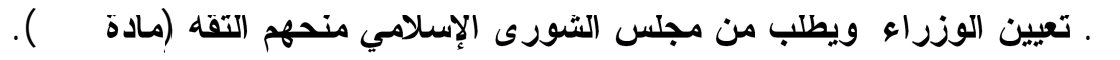

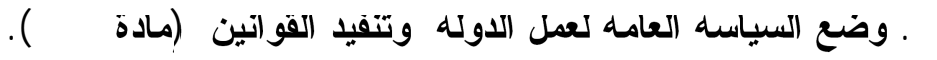

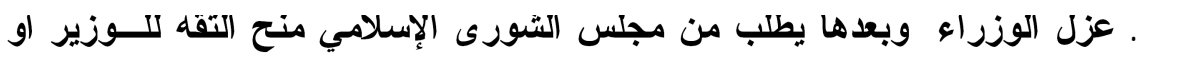

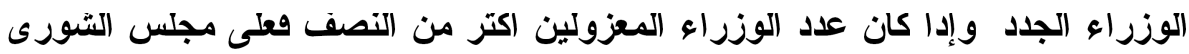

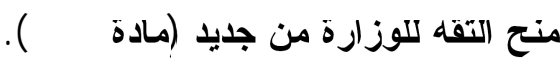

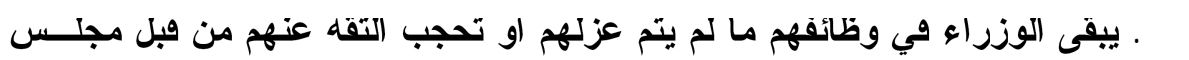

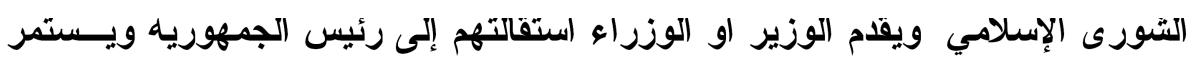
الوزير او الوزارة كافه وي القيام بمهامهه حتى يباثر الوزير الجديد او الوزارة الجديدة،

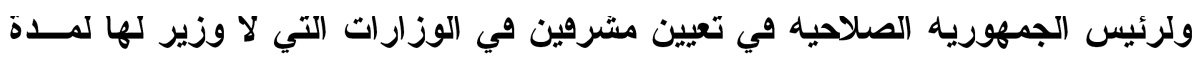
(وصاها شهر واحد (مادة ما ـ يكون كل وزير مسؤولا عن تنقيد واجباته امــام رئسيس الجمهوريـهـه ومجــس

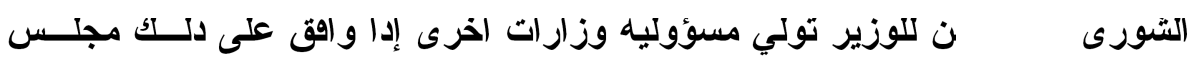

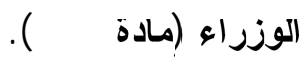
سا ـ إمرار رئيس الجمهوريه لقرارات اللجان التي تتشكل من عدد من الوزراء لتكـــون

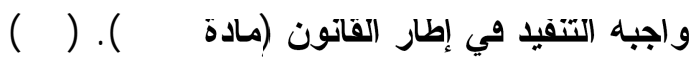


وضلا عما سبق هناك صلاحيات اخرى يتمتع بها رئيس الجمهوريه وينص عليهـ

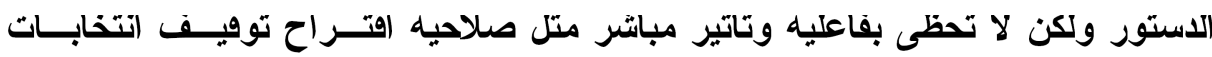
المناطق المحتله، وانتخابات جميع البلاد ولمدة محدودة وـــي زمسـن الحــرب والاحـتلال

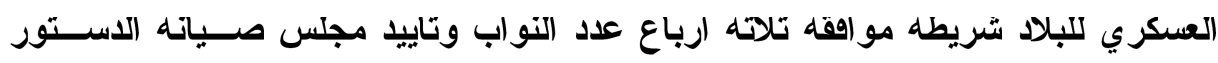

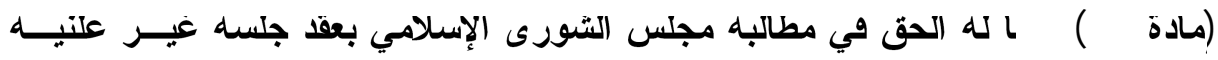

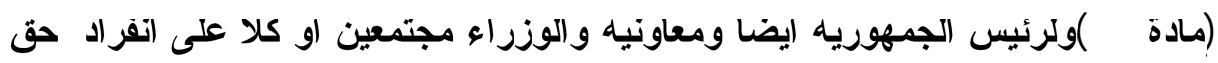
حضور جلسات مجلس الشورى الإسلاهي (مادة -V) وعادة تكون هــــاه الــصلاحيات دون تاتير وهاعليه لان الاستور لم يجز لرئيس الجمهوريه ولا للوزراء صلاحيه التشريع بــاي

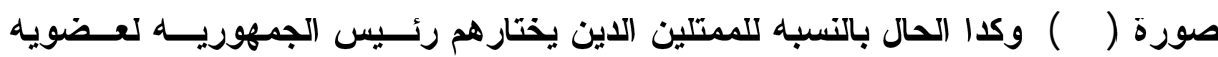
المجلس الاي يتشكل لإدارة مؤسسه الإداعه والتلفزيون بعد إفاله رئيسها، وهذه المهـــه

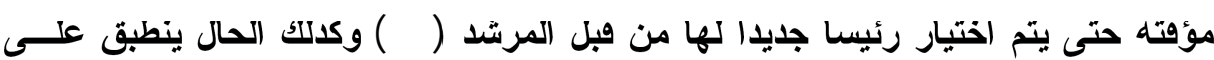

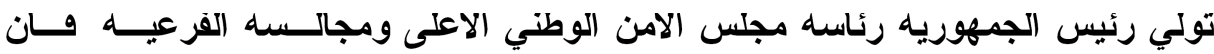

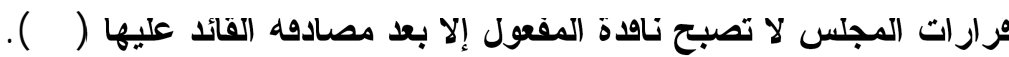
يتضح مما سبق السلطه التنقيايه المتمتله برئيس الجمهوريه ورغم توليه رئاسه

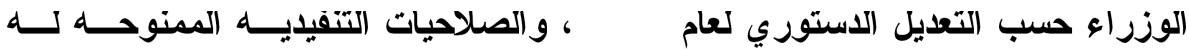
بموجب الاستور ايضا، رغم كل دلك قان الصلاحيات التتقيديه لرئيس الجمهوريه مقيدة ايضا بموجب الاستور، من خلال مسؤوليه رئيس الجمهوريه امسـام مجــس الــشورى

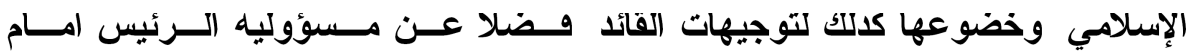

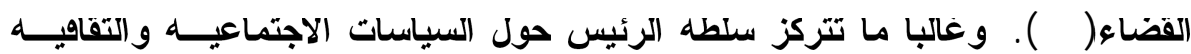
والاوتصاديه للاوله، وليس حول الـسياسه الخارجيـهـ، ونتيجـهـ للقيـود الدسـتوريه المقروضه على منصب الرئيس، فان ووته ليست بالقوة التي يتميز بها هلا المنصب في الدول الغربيه. ليس هلا ححسب بل ان رئيس الجمهوريه في إيران والدي ينتخب بصورة مباثرة من وبل الثبب لا يباشر منصبه حتى يصادق عليه القائد، الــــي هــو بطبيعـهـ

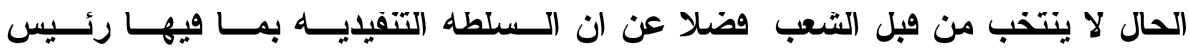

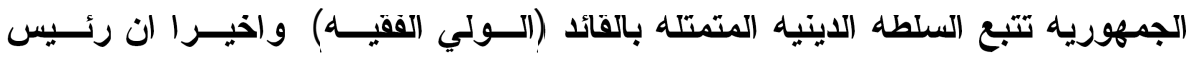


الجمهوريه وي إيران او اي مسؤول في السلطه التنفيديه ليس له اي سيطرة او ســلطه

سياسيه على القوات المسلحه(19).

تالتا: السلطه التشيريعيه

تتكون السلطه التشريعيه وي إيران من مؤسستين هـــا مجلـس الــشورى

الإسلامي (البرلمان) ومجلس صياته الدستور .

$$
1
$$

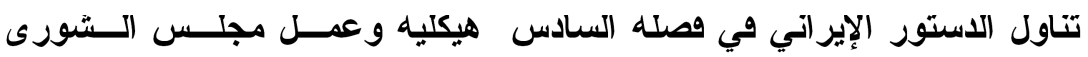

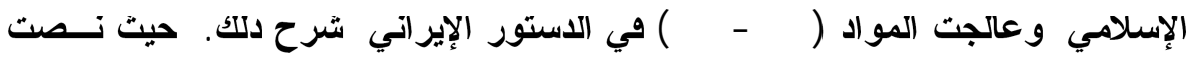
(المادة Tr) على ان مجلس الثنورى الإسلامي يتكون من نواب الشعب الاين يتتخبـون

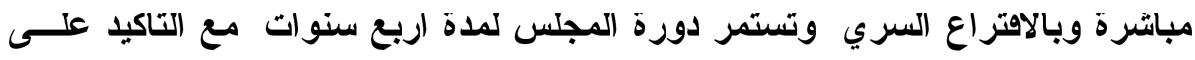
ضرورة انتخاب الدورة الجديلة فبل انتهاء هترة الدورة السابقه حتى لا تبقى البلاد بدون

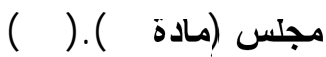

يتالف مجلس الثورى الإسلامي من ( · (IV) نائبا، مع مراعاة زيادة عدد النواب بواقع عشرين نائب لكل عشر سنوات بحسب التفير الايمغراهي والسياسي هـي الــبلاد،

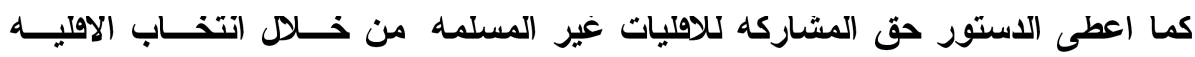

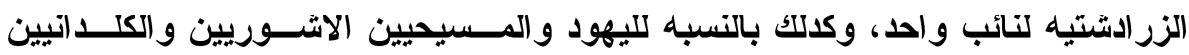

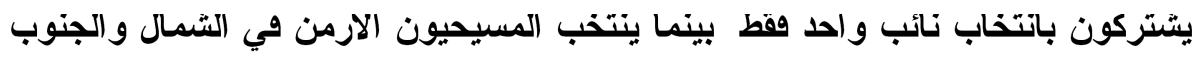

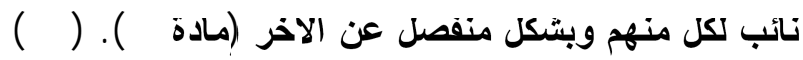
ويشترط في اعضاء المجلس ان تتوفر ويهم صفه الإيمسـان والتقـوى والآتــزام

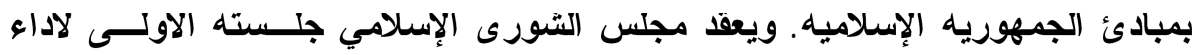

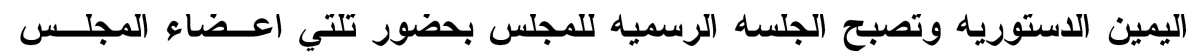
حيث تتم المصادوه على المشاريع واللوائح القانونيه وهق النظام الداخلي الــــي يقــره (المجلس (مادة 70).

ويعقد المجلس جلساته بشكل علني، وتتشر تفاصــيلها عـن طريــث الإداعـهـ و الجريدة الرسميه لغرض إطلاع الراي العام، كما يحق للمجلس ان يعقد جلــسه غيسر

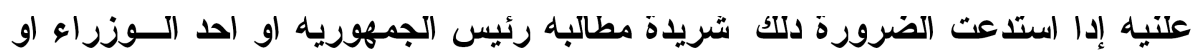


عشرة نواب دلك، وتكون ورارات هده الجلسه هاتونيه إدا اصرها تلاته اربــاع المجلـس

(مادة (79).)

وتتمتل الصلاحيات التي يمتلكها المجلس بالنقاط الاتيه:

I - سن القواتين في كافه القضايا ضمن حدود الاستور المقررة، مي ضرورة تطابقهـ

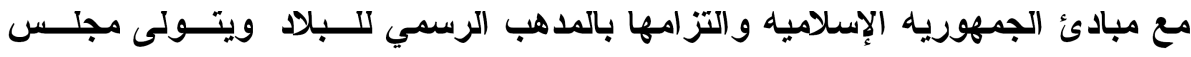

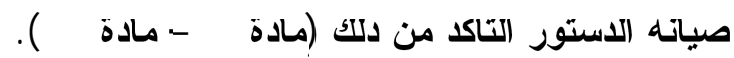

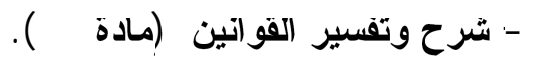

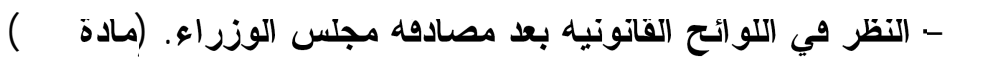
ع - مناهشه اللوائح التي يقدمها بعض النواب والخاصه بخفض او زيادة الإقفاق العـام (مادة (vo)

0 - التدويق و التحقيق في جميع شؤون البلاد. (مادة V7)

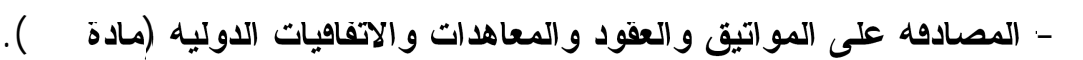
V الوطنيه دلك، شريطه مواوقه الغالبيه العظمى من اعضاء المجلس إمادة VA). A - روض إعلان الاحكام العرويه، إلا وي الحالات والظروف الاضطراريه حينها يواهـث المجلس عليها، شريطه عدم تجاوزها تلاثين يوما. (مادة V9) 9 - المصادهه على عمليات الاقتراض والإقراض التي صد تجريها الحكومه داخل الــبلاد وخارجها. (مادة - (A)

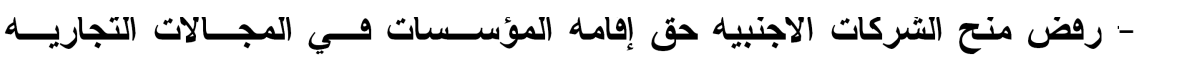

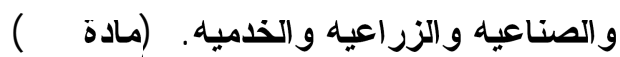
1 I - المصادوه وفي حالات الضرورة على اجراء الحكومه الاستعاته بــبعض الخبــراء الاجانب. (مادة Ar) ما - لا يسمح بنقل ملكيه عقارات الدوله او المباتي التراتيه او الاتريه إلى ملكيه احـد

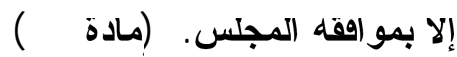
r) 
عا - حق مجلس الشورى في مساوله رئيس الجمهوريه او اي وزير، شريطه مواوقـهـ

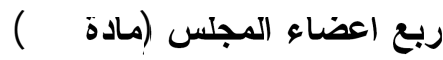

10 - استقبال الشكاوى و النظر ويها، ويما يخص عمل المجلس او الخاصــه بالـسلطه

التقفيديه او السلطه القضائيه، و التحقيق ويها (مادة - 9). (rr)

يرتكز البرلمان الايراني في ملامحه الاساسيه على مبال الحركه الاستوريه التــي

اعقبت التورة الإير انيه عام 0 -19 ، ويملك فارا كبير ا من الحيويـهة، وكتيـر ا مساتكون

المنافشات داخله محتلامه وساخنه(عَ).

يتبين لنا من الصلاحيات الواسعه التي يتمتع بها مجلس الشورى الإسلامي، إن

الاخير يعد من المؤسسات الاستوريه الفاعله وي عمليه صنع القــرار، ضــمن النظـــام

السياسي في إيران. وتتاتر ووة هدا المجلس بعوامل منها، التقل السياسي لتيار الاغلبيه

فيه. وموفف القائد منه، وعلاهته بمجلس صيانه الاستور(ro).

\section{r - مجلس صيانه (الاستور}

يعد مجلس صيانه الاستور المكون التاني للسلطه التشريعيه، ووكرة إنسشاء هـــا

المجلس مستمدة من فكرة مجلس الحكماء الدي تاسس بمناسبه التورة الاستوريه عــام

7-19، من بعض رجال الدين للنظر في القوانين والتحقق من ملى مطابقتها مع احكام الشريعه الإسلاميه، لكن هلا المجلس وقل الهيته واضمحلت واعليته بعد التورة البيضاء

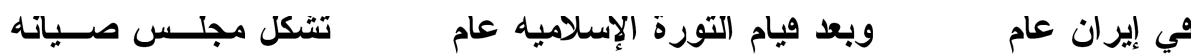

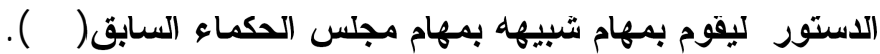

يتكون هدا المجلس من (Ir) عضوا،وهؤلاء الاعضاء هم مجموعه من الفقهــاء و القانونيين، الفقهاء وعددهم سته يختارهم القائد بشكل مباشر، و السته الاخرون هم من مختلف التخصصات القانونيه الدين يرشحهم رئيس السلطه القضائيه، ويصادق علـيهم مجلس الشورى الإسلاهي (مادة|9). وحدد الاستور الإيراني مدة دورة المجلس بـست

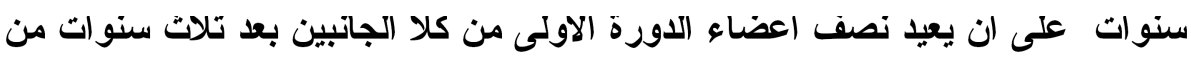

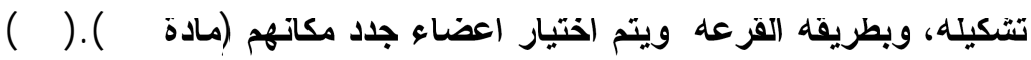

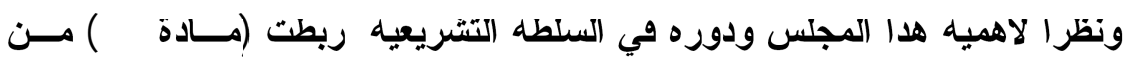

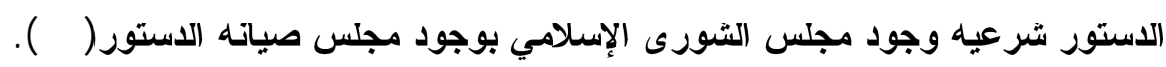
وتتمتل المهام و الصلاحيات التي يقوم بها المجلس بالاتي: 
اولا: النظر في القواتين والتشريعات التي تصدر عـن مجــس الـشورى الإســلاهي، و التحقى من مدى مطابقتها لاحكام الثريعه الإسلاميه، ويتولى دلك وقهاء مجلس صياته الاستور، اما ويما يخص عدم تعارض القوانين والتشريعات ببنود الدستور بثكل عــام،

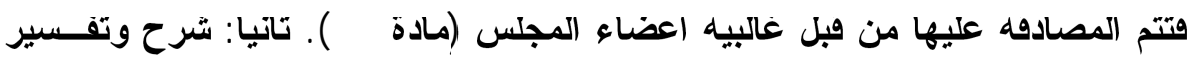
الاستور بعد مصادوه تلاته ارباع اعضاء المجلس. تالتا: الإشر اف على اتتخاب مجلـس أسل خبراء القيادة ورئيس الجمهوريه واعضاء مجلس الثورى الإسلامي وعلى الاســتفتاء

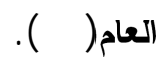

لقد تمتع هدا المجلس بتاتير وتقود وويين وي صياته القـــار السسياسي فـي إيرانه إلى درجه اته يعيد النظر في القوانين الصادرة عن مجلس الشورى الإسـلامي،

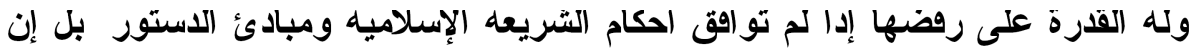
الاستور ربط بين شرعيه وجود مجلس الشورى الإســلاهي بوجـود مجلـس صـيانه الاستور، ليس هلا وحسب بل إن التعديلات التي شهـها الاستور الإيراني عسام

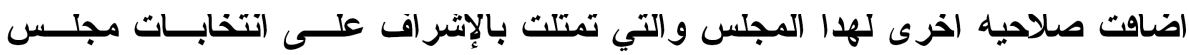
خبراء القيادة ورئيس الجمهوريه واعضاء مجلس الثورى الإسلامي وعلى الاســتقتاء العام، وصد زادت هله الصلاحيه من ووة وتاتير المجلس من خلال منحه صلاحيات روابيه على مؤسسات فاعله وي صناعه القرار السياسي في إيران( - ع).

رابعا: السلطه القضائيه

تعل السلطه القضائيه جزءا من النظام السياسي في إيران، وهي المكمل للسلطتين، التشريعيه و التتقيديه، ونص دستور جمهوريه إيران الإسلاميه وي مادته (107) علم إئه ان السلطه القضائيه هي سلطه مستقله، تداقع عن الحقوق الفرديه والاجتماعيه، وعليها مسؤوليه إحقاق العدالهال (ع). وتحددت وظائف السلطه القضائيه بالمهام الاتيه: التحقيق وإصدار الحكم بخصوص التظلمات والاعتلاءات والثكاوى، والفصل هـي التي الاعاوى، والخصومات واتخاد القزارات و التلابير الكلزمه. 
صيانه الحقوق العامه، وبسط العداله والحريات المشروعه. الإشراف على حسن تتقيا القواتين.

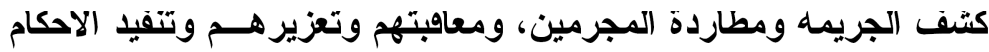

الجز ائيه الإسلاميه المدونه.

اتخاد التدابيز اللازمه للحيلوله دون وهوع الجريمه، ولإصلاح المجـرمين إمـــادة

.(ع) (107

تباشر السلطه القضائيه اعمالها من خلال هيكهها الإداري والتطبيقي او يتراســها شخصا عادلا ومجتهلاه ملما بالامور القضائيه يتم اختياره من فبـلـل القائـــه ويـستمر رئيسـ السلـــطه القضائيه الدي يعتبر اعلى مسؤول فيها، في منصبه هدا مدة خمس سنوات ("ع) ويمارس رئيس السلطه القضائيه المهام الاتيه: • إيجاد الدوائر اللازمه في دوائر العدل بشكل يتناسب مع المسؤوليات المدكورة هـي المادة (107) من الاستور.

• إعداد اللوائح القضائيه المتتاسبه مـع نظام الجمهوريه الإسلاميه.

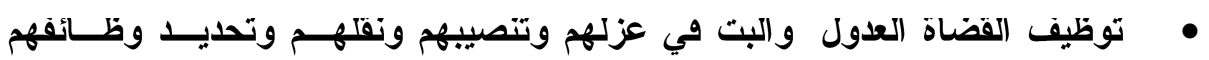

وترويع درجاتهم وما شابه من الامور الإداريه ووقا للقاتون (مادة 10 1).(ع) اما فيما يخص وزير العدل فاته ياتي في سلطته الإداريه بعد رئـيس الـسلطه القضائيه، الدي يتولى مسؤوليه ترشيح الاشخاص لــوزارة العـدل، ويتــولى رئـيس الجمهوريه بدوره اختيار احد هؤلاء لشقل منصب وزير العدل، الــدي يتــولى بـدوره مسؤوليه العلاوه بين السلطه القضائيه من جهه و السلطتين التشريعيه والتتفيديــه مــن جهة ثلانية. ويحق لرئيس السلطه القضائيه منح وزير العدل صلاحيات إداريه وماليــه. واخرى خاصه بتعيين غير القضاة المادة - 17).(0) كما يتولى رئيس السلطه القضائيه تشكيل المحكمه العليا للبلاد إمكمه التمبيز او التقض)، التي تتولى مهمه إعادة التظر في الاحكام الصادرة ومتابعه تتفيد القوانين فـي المحاكم، وسير القضاء (مادة 17) ويقوم كدلك بتعيين كل من رئيس المحكمه العليـا و المدعي العامه بالتشاور مع وضاة المحكمه العليا ولمدة خمس سنوات (مادة r11) كما يشرف رئيس السلطه القضائيه على دائرة|(التقتيش العام) التي تتابع التتفيـــ الــصحيح

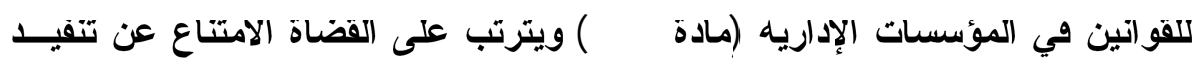


القرارات و اللوائح الحكوميه المخالفه للقو انين والاحكام الإســلاميه، او الخارجــه عـن

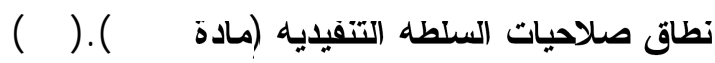

$$
\text { ويوجد وي إيران تلاته انواع من المحاكم: }
$$

النوع الاول: هو المحاكم العامه وهي التي تنظر في كافه القضايا، باستتناء القضايا التي تقع ضمن اختصاص المحاكم التوريه او الخاصه. النوع التاني: هو المحاكم التوريه التي تنظر في: الجرائم الموجهه للامن الاخلي و الخارجي. إهانه مؤسس الجمهوريه الإسلاميه الإمام الخميني، او النقا لاداء المرشدا. التامر ضد النظام وممارسه التخريب ضده. التجسس. تهريب المخلرات. الربح غير المشروع.

النوع التالث: هو المحاكم الخاصه، متل محكمه الاسرة التي نص الدسـتور الإيرانسي

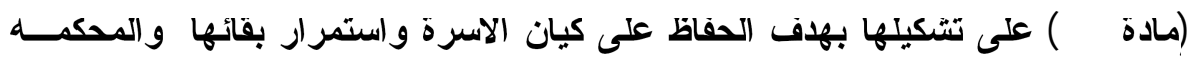

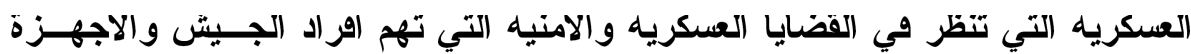
الامنيه، والمحكمه الصحفيه الخاصه بقضايا الصحاهيه و المطبوعات، اما محكمه رجسال الاين فاتها مختصه بالنظر في القضايا الاتيه: 1) التامر ضد القيادة او توجيه الإهانات إليها من وبل رجال الدين. r) كاهه الاعمال والتصروات غير الثرعيه التي يرتكبها رجال الدين. ") كافهالمنازعات المحليه المخالفهللاهن العام التي يكون احد الخصوم ويها من رجـال الدين ع) جميع القضايا التي تدعو القيادة إلى النظر فيها(عV). 
: مجمع تشخيص مصلحة النظام

تاسس هلا المجمع بامر من الإمام الخميني عام 19MM، للبت وي الخلاف الـــي

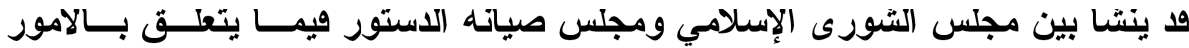

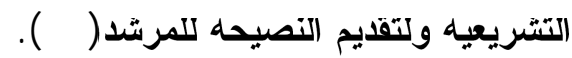

يتالف المجلس من اتتي عشر عضواه وهم رؤساء السلطات التلات إ(التـشريعيه و التنقيليه و (القضائية)، وفقهاء مجلس صياته الدستور، وممتل عـن القائســ، ورئسيس الجمهوريه، والوزير الاي يتعلق القانون او القضيه الخلافيه بوزارته، ووسعت هيكليـهـ

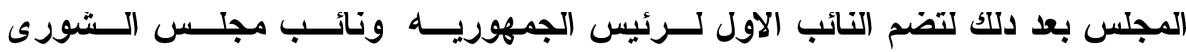
الإسلاهي، وممتلين عن الوزارات السياسيه وي البلاد (9ع) وبعــــ ان كانــت رئاســهـ المجمع توكل إلى رئيس الجمهورياه، اصبح القائد ومند عام 1991 يتولى تعيين رئيسا . (0 - ) d بعد التعديل الدي شهده الاستور الإيراني عام 1919 وسعت صلاحيات ووظـــائف المجلس بشكل كبير لتشمل فضلا عن البت في الخلاف بين مجلس الثورى الإسـلامي وصياته الاستور الوظائف التاليه: I. الإسهام وي وضع السياسه العامه للنظام بالتشاور ميع القائد.

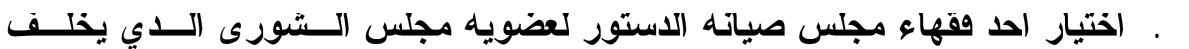
القائد في حاله وواته او استقالته او عزله.

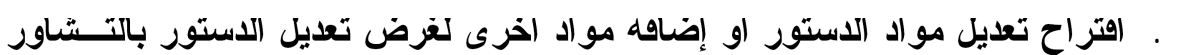
مع المرشد. ع. المشاركه في تشكيل مجلس إعادة النظر في الاستو/(01)ر. وود اتارت الصلاحيات الموسعه للمجمع إثكاليه وي هيكليـهـ النظــام الـسياسي ومؤسساته الاستوريه من خلا منافته للسلطات التلات الاخرى، وعلاهتــهـ المباثــرة

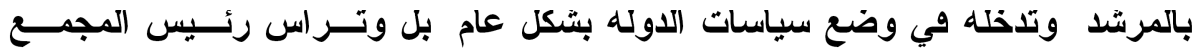

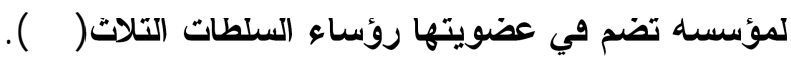
ان وضع السياسه العامه من هبل القائد وبالتشاور مي مجمع تـشخيص النظــام يعني ان وظيقه المجمع تكون استثاريه ووراراته التي يقدمها للمرشد تعتبر غير ملزمهـ

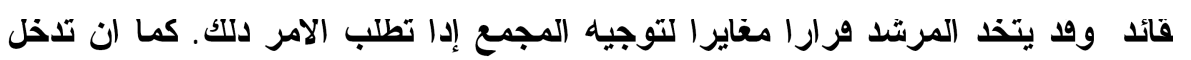
المجمي في الفصل في القضايا بين مجلس الشورى الإسلامي ومجلس إعادة النظر هـي 


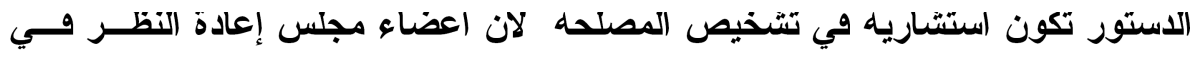
الاستور معينين وليس منتخبين متل مجلس الشورى الإسلامي، وعليه ان ياخد في نظر الاعتبار عند تنشيص المصلحه راي مجلس الـشورى الإســلامي بوصــفه مؤسـسـه

منتخبة(Or).

تم تشكيل مجلس الامن القومي الاعلى بموجب المــادة (IV7) مسن الدسـتور الإيراني، والهدف من تاسيس هلا المجلس هو تامين المصالح الوطنيه وحراسه التورة الأبل الإسلاميه والحقاظ على وحدة وسلامه ار اضي البلاد و السيادة الوطنيه(0ع).

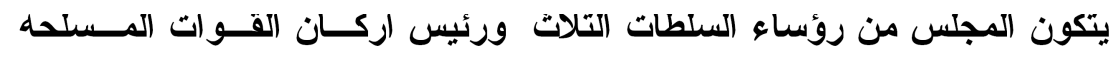

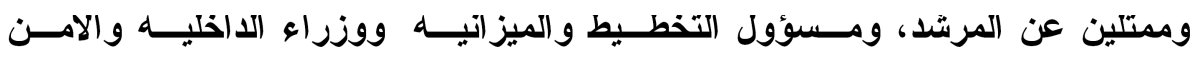

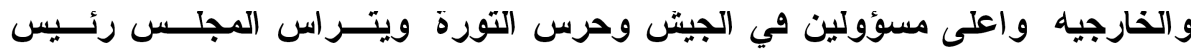
الجمهوريه الدي هو وي الووت داته يمتل رئيس السلطه التتقيديهان(00). يتولى المجلس تتفيا المهام التاليه: 1 - تعيين السياسات الدهاعيه والامنيه للبلاد وي إطار السياسات العامه التــي يحـددها القائد . م - تتسيق النشاطات السياسيه، و الامنيه، و الاجتماعيه، و التقافيـه، والاوتــصاديه دات العلاهه بالخطط الدهاعيه - الامنيه العامه.

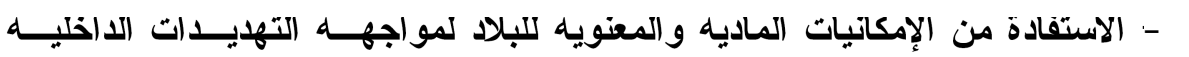
والخارجيه. ع - تعيين المجالس الفرعيه متل مجلس الدهاع ومجلس امن الــبلاد. ويتـراس هــــه المجالس رئيس الجمهوريه، او يتولى اختيار احد اعضاء مجلس الامن القومي الاعلــى لرئاستها نيابه عنه(07). 
مسابقا: مجس خبر اء القيادة

تاسس هدا المجلس عام 19V9، لغرض مراجعه مسودة الاستور التــي اعـدت

للاستفتاء الشعبي، وتالف المجلس في بدايته من سبعين عضواه ليرتفع عام ra19 إلى

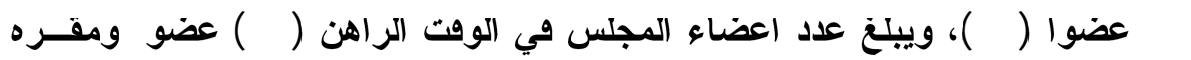
مدينه ومه وبامكان المجلس عزل المرشد الاعلى إدا اصبع عــاجزا عـن اداء مهامــه المكلف بها، او هقد شرطا من الشروط الواجب توفرها ويه لشقل هدا المنــبـ، او إدا تبين بعد دلك انه لم يكن يملكها وي الاصل، ويجتمع اعضاء المجلس مرة واحدة كل عام لمدة يومين، وضلا عن الاجتماعات الطارئه وفت الازمات، ويشغل اعـضـاء المجلـس وظائف مهمه وي مؤسسات الدوله، ويتخب الشعب الإيراني شخصا واحــــا عـن كـل محافظه، والبالغه Y M محافظه، وإدا زاد عدد سكان المحافظه عن مليون شخص يحـق لها انتخاب ممتل اضافي لها وي المجلس عن كل نصف مليون شخص، (ON) ومعظــ اعضاء المجلس هم من كبار رجال الدين البارزين، كما حددث مدة دورة المجلس بتمان سنوات، امـا مهام المجلس وتتمتل في اختبار وتعيين وعزل المرشـــ الاعلــى للتـورة (الإسلاميه(09).

شالمنا: مجلس إعادة التظر في الدستور تتم إعادة النظر في بنود الاستور الإيراني لغرض تعديلها بحدف او إضاهه مــواد اخرى، من هبل مجلس خاص يتم تشكيله، إدا (قتضت الحاجه إليه ويطلق علـى هــــ

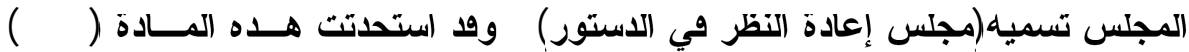

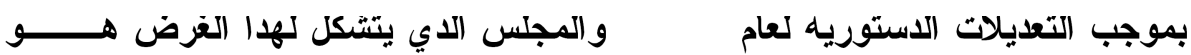
الدي يتولى مسؤوليه التعديــــل، اي ان مجلس الشورى الإسلامي ليس له علافه بـهده

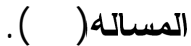

واليه عمل تعديل الاستور تتم من خلال تشناور المرشد مـــع مجـــع تــشخيص مصلحه النظام في تحديا البنود المراد تعديلها بالحدف او الإضاهه لإكمال الاستور، ويتم بعدها إرسال ورار إلى رئيس الجمهوريه بهـا الخصوص، تم توجه الدعوة إلى اعـضاء المجلس للاجتماع لها الغرض. واعضاء المجلس هم: I. اعضاء مجلس صيانه الاستور. r. الاعضاء الأئمون وي مجمع تشخيص مصلحه النظام. 


\section{[Ivo]}

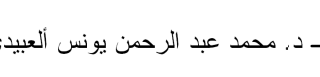

r. خمسه اعضاء من مجلس خبر اء القيادة. ع. عشرة اشخاص يختارهم القائد. 0. تلاته انخخاص من مجلس الوزراء. 7. تلاته اشخاص من السلطه القضائيه. A A. تلاته اشخاص من الوسط الجامعي/ (7) . تعرض القرارات والتعديلات الصادرة من هذا المجلس للاستفتاء الشُعبي العــامه

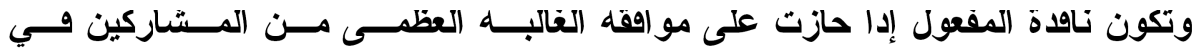

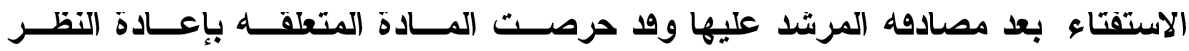
بالدستور على استبعاد مواد الدستور المتعلقه بالنظام الجمهــوري الإســلامي وولايـــه

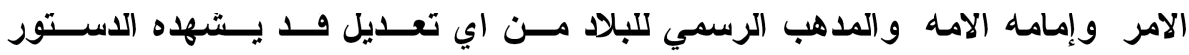
الإير اني(T).

الخاتمه

يتصف النظام السياسي في إيران بمر اكز سلطه رسميه وغير رسميه، حيث تتمتـلـ مراكز السلطه الرسميه وي الاستور و التشريعات الحكوميه وتاخد شكل مؤسسات الدوله واجهزتها، اما مراكز السلطه غير الرسميه وتـشمل الجمعيـات الدينيـه -الـسياسيه و والمؤسسات التوريه. يتولى رئيس الجمهوريه بصفته رئيسا تتقيديا، مسؤوليه الإلدارة اليوميـه للــبلاده. ولكنه على اي حال، لا يحدد الموجهات العامه للسياسده الإيرانيه الاخليه و الخارجيـهـه.

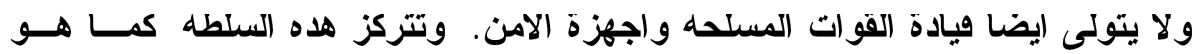
منصوص عليها وي الاستور، وي يد (المرشد الاعلى) الدي يعد اهوى مراكز الدز السلطه في

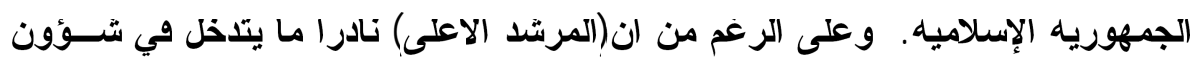

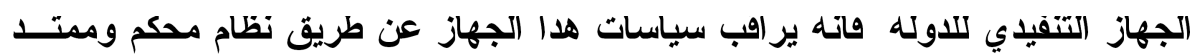
وي كافه اتحاء البلاد. 
ويمكن القول ان النظام السياسي في إيران لا يمكن ان يوصف، مسن وجهــه

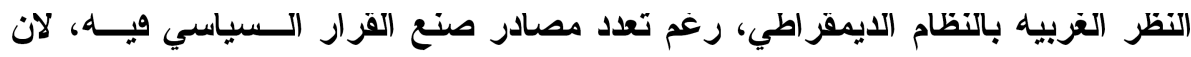

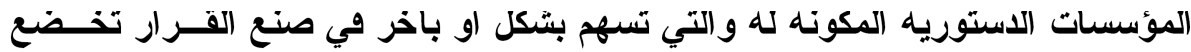

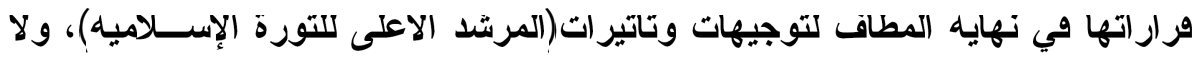
تكون ناصدة إلا بعد مصادهته عليها. ويعد هلا النظام من النظم الإسلاميه الثموليه، وهو اهرب وي طبيعته إلى صفه النظام المركزي، لكنه يتمتع بنوع من الــسمه الديمقراطيـهـ داخل نظامه الداخلي والدي يسيطر عليه رجال الدين المتشدادين والتي تكـــون مقتـــرة

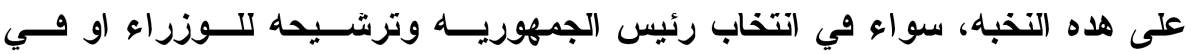
استجو ابهم و إمكانيه حجب التقه عنهم من فبل مجلس الثورى الإسلامي. ضضلا عن دلك ان النظام السياسي في إيران يتميز عن الكتير من الانظمه السياسيه في العالم، إد يضم

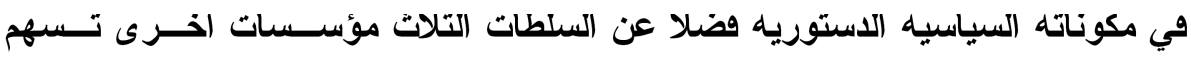
بشكل مباثر في صنع القرار السياسي اولها القارة على التاتير على تغييـر او تعـديل القرارات الاخرى الصادرة عن السلطه التشريعيه. 


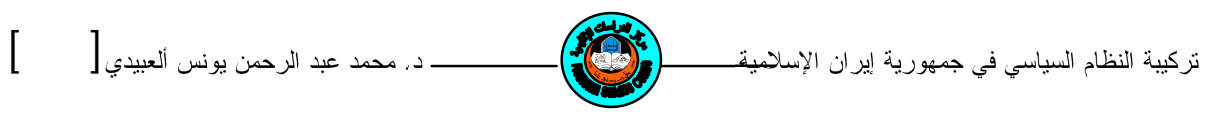

\title{
The Structure of Political System In Islamic Republic of Iran
}

Dr. Mohammad Abdul Rahman Younis AL-Obaidy*

\begin{abstract}
Political system in Iran is characterized by its religious . It depends upon the principle of the Islamic government based on the concept theory of (Wellayat Al-Fakih) as a basis for the reign . Political system of Iran is also characterized by centralization as well as its complicated and compound nature which differs from so many political systems in the world .According to its structure, constitutional institutions forming this system lie within the three powers ( legislative, judicial and executive) as well as independent institutions.

These institutions share in addition to religious and political societies and revolutionary ones and Al-Bazaar, in making the political decision. Constitution of Iran has defined the structure and Competence of these institutions and limited its functions. These competences might differ and cases arose can be solved by the superior. Guide of Islamic Revolution as being the high authority in politics and religion inside the political system of Iran.
\end{abstract}

"Lecturer At The Department of History And Documentation, Regional Studies Center, Mosul University, Iraq. 
(1)

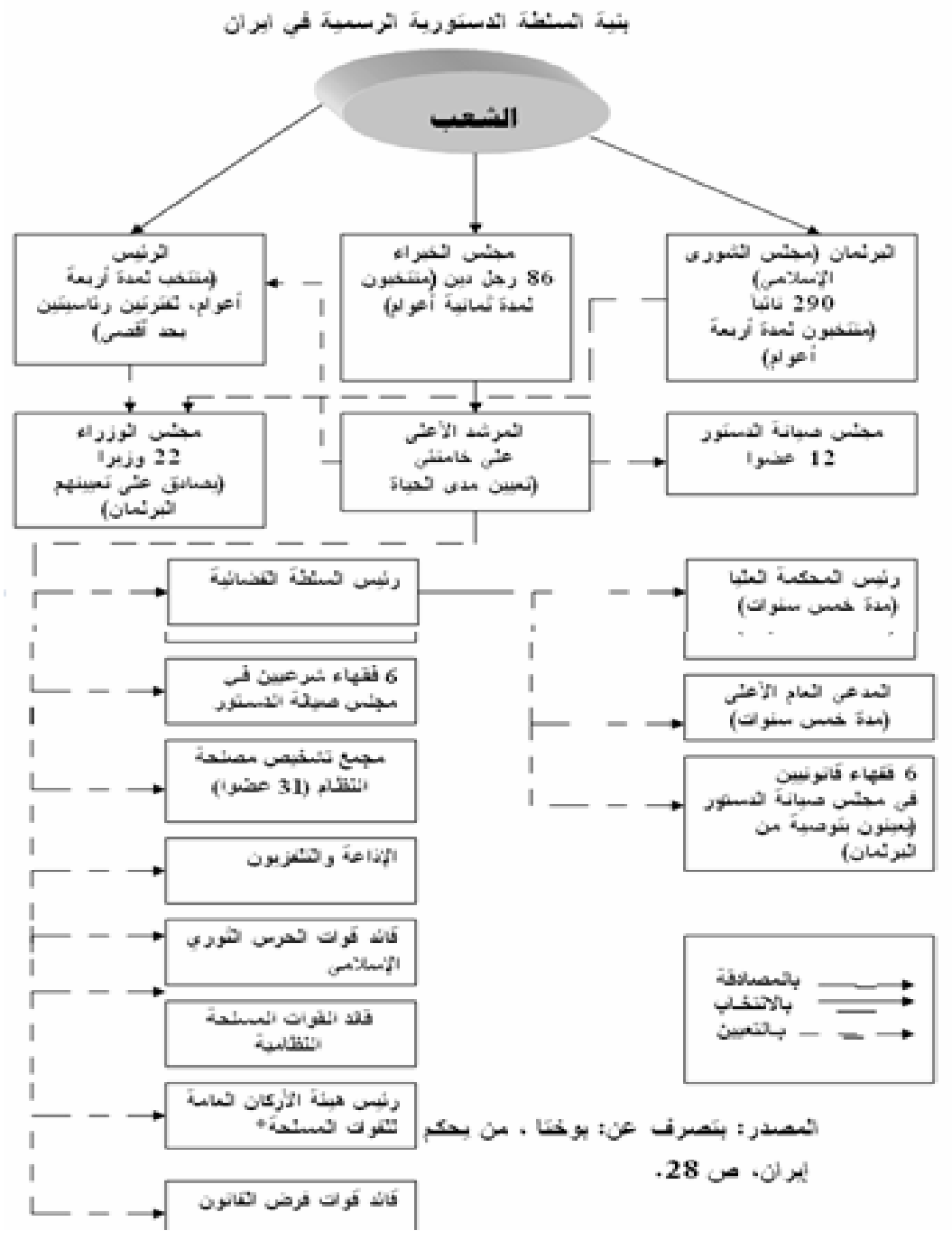


المهو امش و المصادر

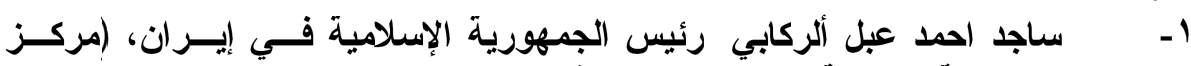

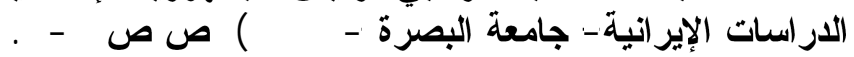

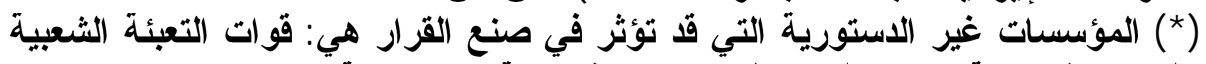

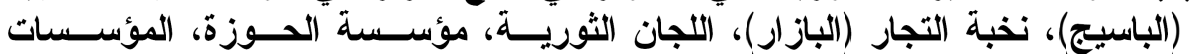

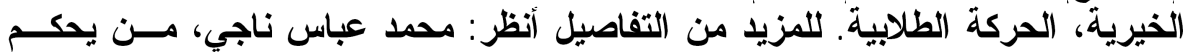

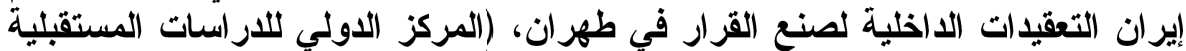

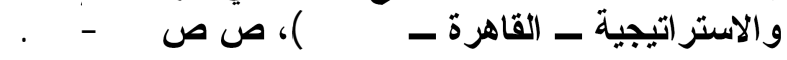

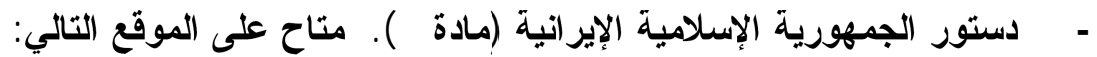

http://www.uuwab.com

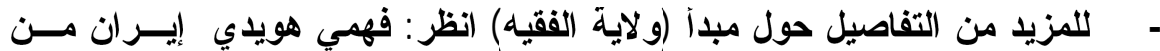

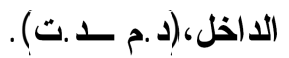

- - دستور الجمهورية الإسلامية الإيرانية (مادة 0).

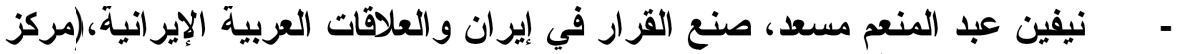

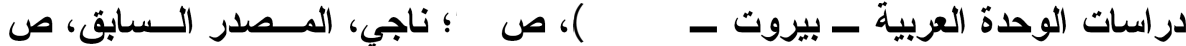

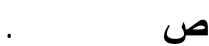

- - ل دستور الجمهورية الإسلامية الإيرانية (مادة OV).

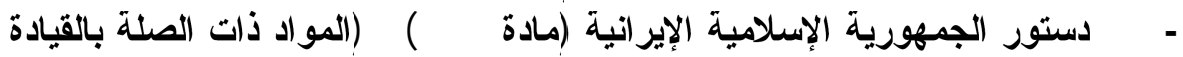

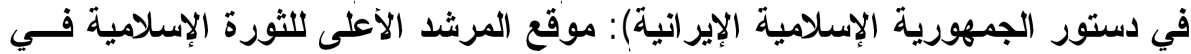

http://www.leader.ir إيران علي الحسيني الخامنئي:

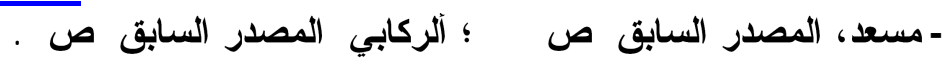

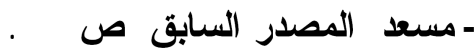

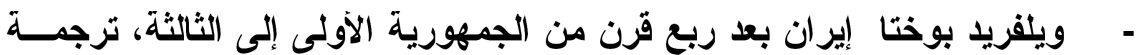

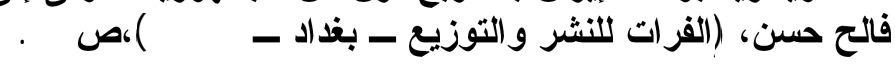

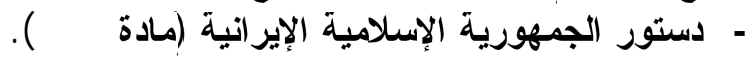

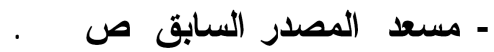

- - ويلفريد بوختا، من يحكم إيران (ابنية السلطة في الجمهورية الإسلامية الإيرانية)،

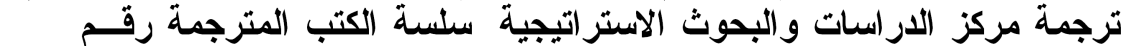

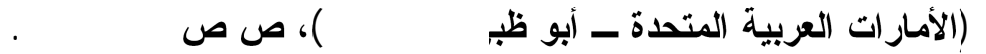

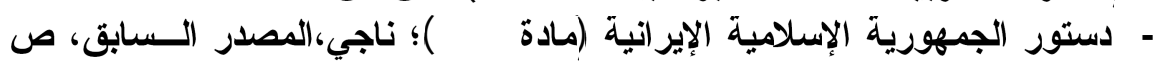

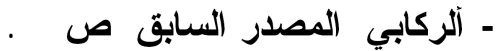

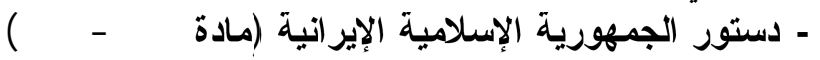




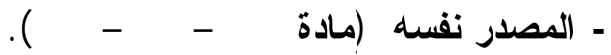

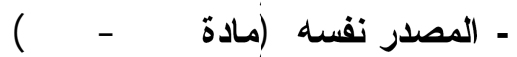

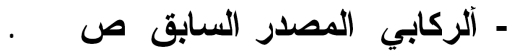

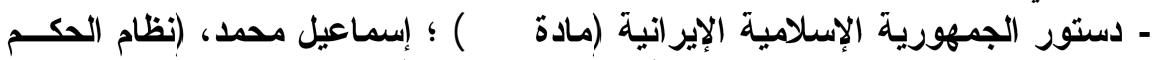
في إيران)، بحث منشور على شبكة الإسلائة المعلومات الدولية (الانترنت) على الموقع: www.aljazera.com

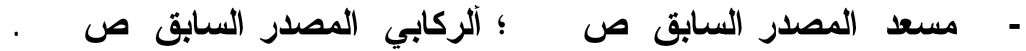

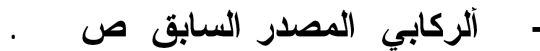

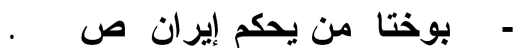

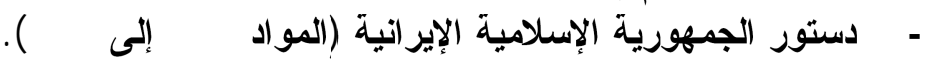

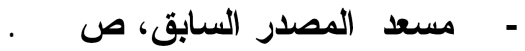

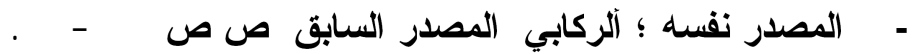

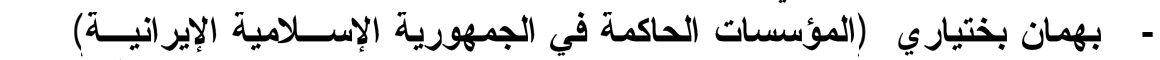

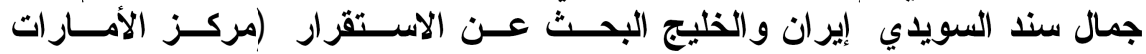

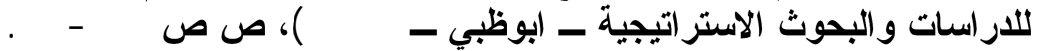

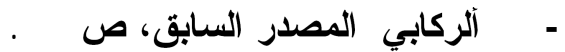

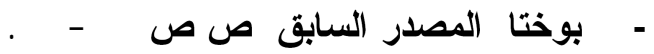

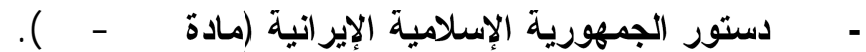

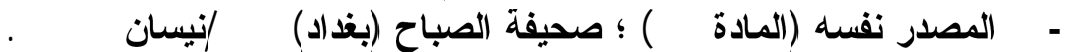

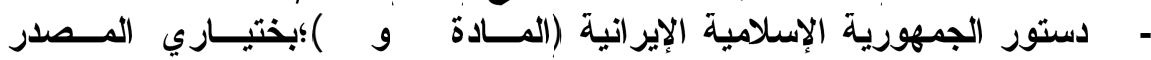

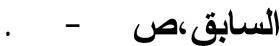

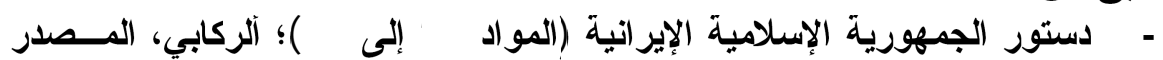

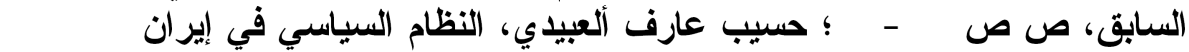

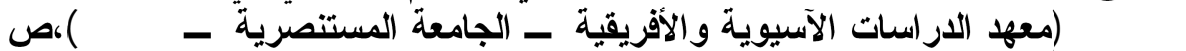

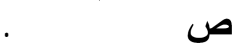

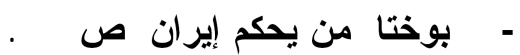

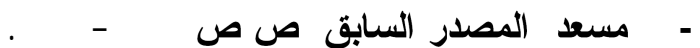

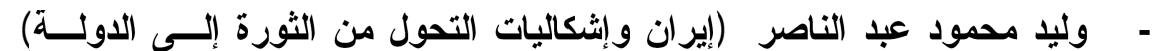

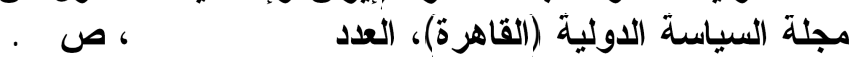

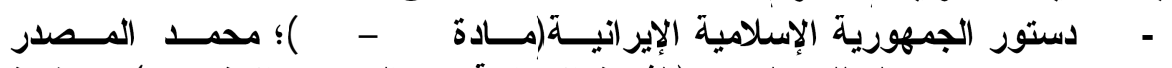

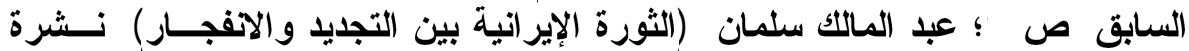
مختارات إيرانية تصدر عن مركز الدارسات السياسية والاستر اتيجية (القاهرة): http://www.ahram.org - دستور الجمهورية الإسلامية الإيرانية(مادة 97)؛بختياري، المـصدر الـسابق، ص90.

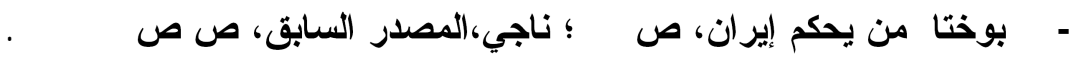

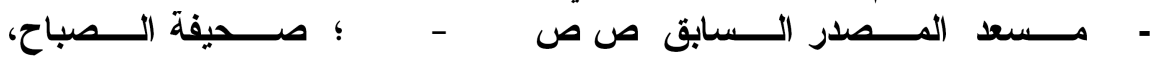
o 0 
$[\mathbf{1 A |}]$ د. محمد عبد الرحمن يونس ألعبيدي

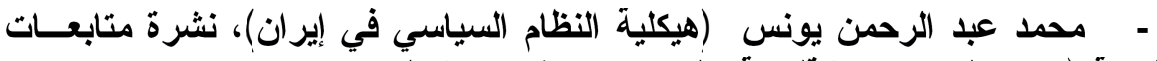

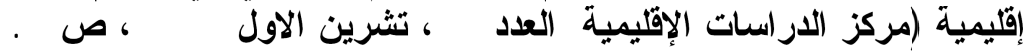

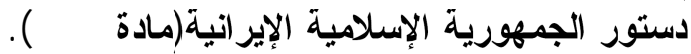

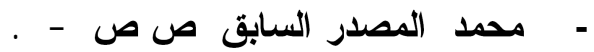

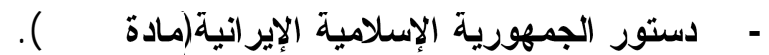

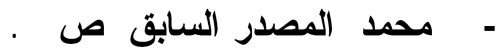

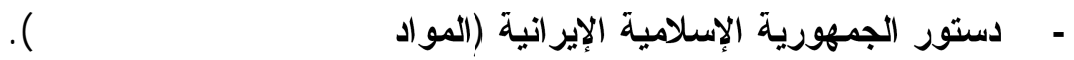

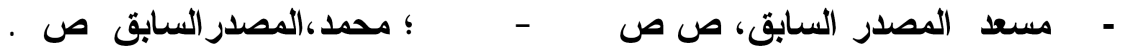

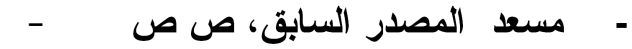

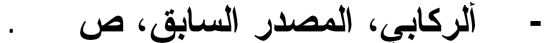

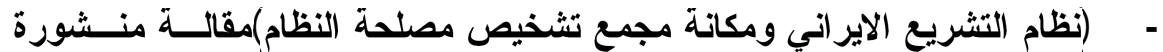

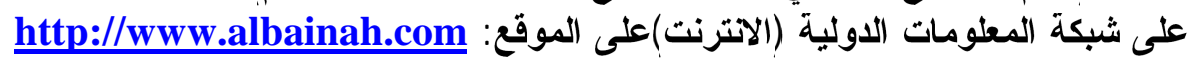

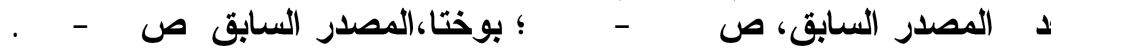

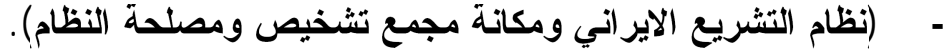

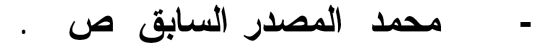

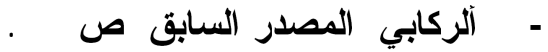

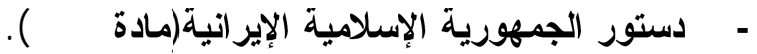

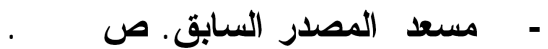

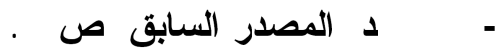

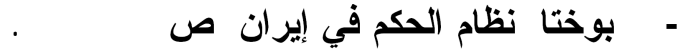

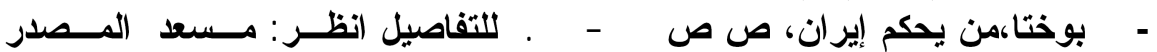

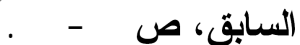

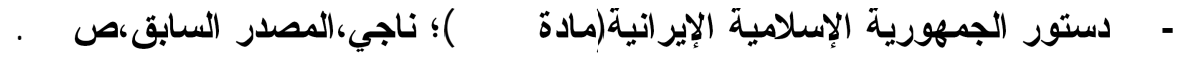

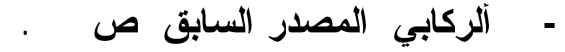

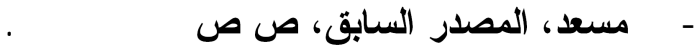

